\title{
Late-season fertilization of Picea mariana seedlings: intensive loading and outplanting response on greenhouse bioassays
}

\author{
Joseph R. Boivin, K. Francis SALIFU, Vic R. TIMMER* \\ Faculty of Forestry, University of Toronto, 33 Willcocks Street, Toronto, M5S 3B3, Canada
}

(Received 5 January 2004; accepted 11 May 2004)

\begin{abstract}
Traditional greenhouse culture involves a late-season hardening period that withholds irrigation and fertilization from black spruce seedlings to promote frost-hardiness. Since nutrient uptake is limited without supplemental fertilization, growth during hardening may lead to internal nutrient dilution, a condition detrimental to field performance of seedlings. We examine whether late-season fertilization, applied as intensive loading, will counter dilution and build up nutrient reserves in seedlings reared conventionally or nutrient loaded before hardening. A mixed NPK fertilizer delivering $0,12,24$, or, $48 \mathrm{mg} \mathrm{N} \cdot$ seedling $^{-1}$ for 9 weeks after bud set was tested. Root and shoot dry mass increased as much as 104 and $42 \%$ during hardening. Seedling biomass, however, was unchanged by late-season fertilization, but $\mathrm{N}$ uptake was increased 44-167\% signifying induced luxury consumption. Extra K supplementation of treatments averted K dilution in plant tissues often occurring with high $\mathrm{N}$ addition. A 13-week outplanting trial on intact soil bioassays retrieved from a boreal site showed that growth and nutrient allocation were significantly enhanced by larger $\mathrm{N}$ reserves built up after intensive nutrient loading. About $72-80 \%$ of $\mathrm{N}$ required for new shoot growth was met from internal cycling, demonstrating the capacity of loading to enhance retranslocation. Intermediate loading ( $24 \mathrm{mg} \mathrm{N})$ was most effective in promoting $\mathrm{N}$ accumulation and outplanting growth of both seedling types. Survival was reduced (30\%) only at the highest dose. Study results demonstrate the potential advantage of these practices to improve growth of newly planted seedlings on northern forest sites.
\end{abstract}

black spruce / hardening period / nitrogen / nutrient loading / retranslocation / super-loading

Résumé - Fertilisation tardive de semis de Picea mariana : apport intensif et réponse après plantation en serre d'essais biologiques. Les cultures traditionnelles en serre comportent une période tardive d'endurcissement qui retarde l'irrigation et la fertilisation des semis de Picea mariana pour promouvoir l'endurcissement au froid. Puisque le prélèvement de nutriments est limité sans supplémentation de fertilisation, la croissance pendant la période d'endurcissement peut conduire à une dilution interne des nutriments, une situation préjudiciable pour les performances au champ des plants. Nous avons examiné si la fertilisation tardive, appliquée par des apports massifs peut contrebalancer la dilution et accroître les réserves de nutriments dans les semis élevés conventionnellement ou les nutriments apportés avant l'endurcissement. On a testé un mélange de fertilisant NPK libérant $0,12,24$ ou $48 \mathrm{mg}$ d'azote par semis pendant 9 semaines après le débourrement. Le poids sec des racines et des pousses s'est accru de 104 et $42 \%$ pendant l'endurcissement. Cependant la biomasse des semis a été inchangée par une fertilisation tardive, mais le prélèvement d'azote s'est accru de 44 à $167 \%$, indiquant une consommation de luxe. Une supplémentation en K évite une dilution en $\mathrm{K}$ des tissus, ce qui arrive souvent avec un apport important d'azote. Un essai à 13 semaines sur un sol pour essais biologiques, extrait d'une station boréale, a montré que la croissance et l'allocation des nutriments étaient significativement augmentées par de grandes réserves d'azote accumulé après des apports intensifs de nutriments. Environ 72 à $80 \%$ de N requis pour la croissance des nouvelles pousses provenaient du cycle interne, démontrant l'importance des apports pour augmenter les retranslocations. Un apport intermédiaire (24 mg N) était plus efficace pour promouvoir l'accumulation de $\mathrm{N}$ et la croissance des deux types de semis. La survie a été réduite (30\%) seulement pour la plus forte dose. Les résultats de cette étude ont démontré l'avantage potentiel de ces pratiques pour l'amélioration de la croissance des semis dans les stations forestières du Nord.

Picea mariana / période d'endurcissement / azote / apport de nutriment / retranslocation / super apport

\section{INTRODUCTION}

Intensive forestry in Canada involves large-scale reforestation programs that require high quality planting stock, conditioned for improved survival, nutrition and vigorous growth after outplanting. However, studies have shown that survival and growth of newly planted conifer seedlings may be reduced by low soil fertility or by intense plant competition [6,20,23].
Hence, nursery treatments that improve early plantation establishment may contribute significantly to reforestation success. Examples of current nursery techniques that have promise for improving field performance of seedlings are exponential fertilization [16, 18, 42, 45] and nutrient loading [37, 47]. These techniques nutritionally prepare and condition trees for the field environment by matching nutrient supply with crop demand to maximize nutrient reserves in seedlings prior to planting [36,

\footnotetext{
* Corresponding author: vic.timmer@utoronto.ca
} 
48]. Superior growth of exponentially nutrient loaded seedlings was attributed to retranslocation of stored nutrients to active growth sinks soon after planting $[24,32,36]$.

Traditional greenhouse cultural practices do not promote the build up of nutrient reserves in seedlings because of late-season cutback of fertilizer for hardening off purposes [4, 10, 22]. The hardening period is defined as the time interval following apical bud initiation when roots and shoots acquire frost hardiness [10]. Apical bud initiation is induced artificially within twoweeks of exposure to short-day photoperiod $(8 \mathrm{~h})$ once seedlings attain a target height $[1,5,9]$. Subsequent fertilization and irrigation are usually reduced during hardening to induce moisture and nutrient stress in cultured plants. This practice may promote seedling drought and frost tolerance for winter storage and subsequent outplanting [12], but may also lower plant nutrient concentration due to reduced nutrient supply and dilution effects associated with growth response despite stress induction [5]. For example, root dry mass increased as much as $200 \%$ [5] and 794\% [33] in black spruce (Picea mariana [Mill.] B.S.P.) seedlings during hardening. Late-season fertilization is controversial, however, since some studies suggest it may negatively affect cold tolerance of conifer seedlings [2], others found no effects on cold tolerance of conifer seedlings [3], while still others report increased frost hardiness after application [35]. There is general consensus that fall $\mathrm{N}$ fertilization benefits subsequent field performance of newly planted trees because of increased $\mathrm{N}$ concentration and contents in the trees [19, 25, 39].

Biomass growth without sufficient fertilization during hardening can severely dilute plant nutrient reserves, thus compromising steady-state nutrition and nutrient loading efforts [2, 5, 28]. Steady-state nutrition is characterized by stable internal tissue nutrient concentration over time free from nutrient stress [17]. This state can be achieved by applying nutrients at exponentially increasing addition rates that correspond more closely with exponential growth and nutrient demand of crops during the exponential growth phase of plants [18]. Compared to constant feed fertilization used conventionally [44], this condition conforms more closely to the natural outplanting environment in terms of supply, flux and acquisition of soil nutrients for newly planted seedlings [30].

We have previously demonstrated that late-season fertilization as nutrient loading during hardening may counter nutrient dilution and further build nutrient reserves in seedlings for improved field performance [5]. At high rates, or extended nutrient loading, this practice effectively induced luxury uptake and raised seedling $\mathrm{N}$ concentration and other nutrient reserves in plants [5]. However, growth dilution still occurred when applications ended, reducing internal nutrient reserves to prehardening levels since uptake could not keep up with rapid growth. The results suggested more intensive loading at even higher rates for longer time periods (or "super loading") might prolong nutrient uptake, avert growth dilution and promote nutrient accumulation in seedlings. We also noted that plant $\mathrm{K}$ uptake was reduced at higher $\mathrm{N}$ addition, which indicated that intensified nutrient loading would need extra $\mathrm{K}$ to maintain nutrient balance in seedlings [5, 49]. The study focused on growth and nutritional development under nursery culture, but did not cover subsequent outplanting performance of test seedlings.
This paper reports on a follow up of the previous study [5]. We test here whether application of super-loading regimes, supplying higher dose rates with longer delivery schedules, can enhance nutrient accumulation during the hardening period. A second objective was to assess whether $\mathrm{N}$ induced $\mathrm{K}$ dilution [5] could be avoided by enriching the applied fertilizer with more $\mathrm{K}(30 \%)$. The final objective was to test effects of intensified nutrient loading on outplanting performance of seedlings using pot bioassays. The general hypothesis addressed was that high-dose, late-season fertilization promotes seedling growth and nutrition under greenhouse culture and outplanting environments, such as on bioassays retrieved from the boreal forest.

\section{MATERIALS AND METHODS}

\subsection{Plant material and pre-hardening fertility regimes}

Black spruce seedlings were grown and over-wintered at a commercial greenhouse (North Gro Development Ltd.) located near Kirkland Lake, Ontario ( $\left.48^{\circ} 10^{\prime} \mathrm{N}, 88^{\circ} 01^{\prime} \mathrm{W}\right)$. Seeds were spring-sown (April, 1999) into $40 \mathrm{~cm}^{3}$ cavities in Styroblock trays (format 470 containing 330 cavities.tray ${ }^{-1}$ ) filled with a peat:vermiculite:perlite mixture $(3: 1: 1, \mathrm{v} / \mathrm{v} / \mathrm{v})$. Germinated seedlings were reared under natural day-length with internal greenhouse temperatures averaging $16: 28^{\circ} \mathrm{C}$ (daily night:day min.:max.). The crops were grown under two fertility regimes before hardening (Tab. I). The first treatment referred to as the conventional $(\mathrm{C})$ fertilization regime (representing industry standard practice), supplied a seasonal total of $19 \mathrm{mg} \mathrm{N} \cdot$ seedling $^{-1}$ based on a constant feed model described in detail by [44]. The second treatment, referred to as nutrient loading (NL) regime, delivered a seasonal total of $74 \mathrm{mg} \mathrm{N}$.seedling ${ }^{-1}$ at exponentially increasing addition rates Timmer et al. [44]. A commercial water-soluble fertilizer (Plant Products $20 \mathrm{~N}-20 \mathrm{P}_{2} \mathrm{O}_{5}-20 \mathrm{~K}_{2} \mathrm{O}$, plus microelements) was applied to both regimes. The nutrient loaded treatment, however, was enriched with more $\mathrm{K}(30 \%)$ to avoid possible $\mathrm{K}$ dilution associated with high $\mathrm{N}$ addition [49]. The extra elemental K was supplied as KCl. Seedlings were sprayed with nutrients as pre-mixed fertilizer solutions using traveling booms with fixed nozzles and were subsequently rinsed with water to avoid fertilizer burn. This commenced one week after germination and was carried out for $14 \mathrm{wk}$ (Tab. I). Irrigation (including fertilization and final rinse) was to container capacity $[46,50]$, which assured that crops were returned to the same level of moisture availability among treatments.

When seedlings reached target height $(16 \mathrm{~cm}, 12$ weeks after germination), a two-week short-day treatment ( $8 \mathrm{~h}$ light with blackout curtains) was imposed to induce terminal bud-set and stop height growth [1]. The hardening period commenced after terminal bud set with a return to natural day-length and a gradual lowering of greenhouse temperatures $\left(7: 18^{\circ} \mathrm{C}\right.$ daily night:day min.:max.). Seedlings were hardened for 18 weeks (Tab. I) and then transferred to a cold storage facility $\left(-2{ }^{\circ} \mathrm{C}\right)$ for over-wintering for about 5 months [11].

\subsection{Late-season fertilization treatments and the experimental design}

Immediately following bud set, four late-season fertilization treatments were tested within the conventionally (C) fertilized or nutrient loaded $(\mathrm{NL})$ regimes. The four treatments were: (i) an unfertilized or control (0) simulating standard industry hardening practices, (ii) an extended loading treatment $(1 \times)$ that supplied a cumulative total of $12 \mathrm{mg} \mathrm{N}$ seedling $^{-1}$ to avoid nutrient dilution [5], (iii) an intermediate

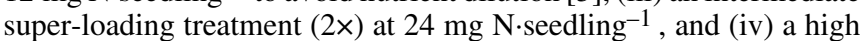

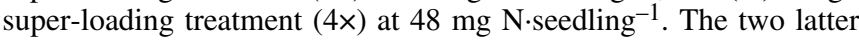


Table I. Treatment schedule for containerized black spruce seedlings during greenhouse culture and after outplanting. The two main fertilization regimes: conventional (C) and nutrient loaded (NL) supplied cumulative totals of 19 and $74 \mathrm{mg} \mathrm{N} \cdot$ seedling $^{-1}$ before budset. The four lateseason fertilization treatments within each of the $\mathrm{C}$ or NL regimes: control $(0)$, extended loading $(1 \times)$, intermediate super-loading $(2 \times)$ and high super-loading (4×) supplied cumulative totals of $0,12,24$ and $48 \mathrm{mg} \mathrm{N} \cdot$ seedling $^{-1}$ after bud set.

\begin{tabular}{|c|c|c|c|}
\hline Year & Week & Cultural phase & Treatment \\
\hline \multicolumn{4}{|c|}{ Year 1} \\
\hline & $0-1$ & Germination & Water only \\
\hline & $1-14$ & Exponential growth & $\begin{array}{l}\text { Main fertilization } \\
\quad(\mathrm{C} \text { and NL) }\end{array}$ \\
\hline & $14-16$ & Bud set & Short day \\
\hline & $18-27$ & Hardening & $\begin{array}{l}\text { Late-season fertilization } \\
\quad(0,1 \times, 2 \times \text { or } 4 \times)\end{array}$ \\
\hline & $27-36$ & Hardening & Water only \\
\hline & $36+$ & Cold-storage & \\
\hline \multicolumn{4}{|c|}{ Year 2} \\
\hline & $0-13$ & Outplanting & Water only \\
\hline
\end{tabular}

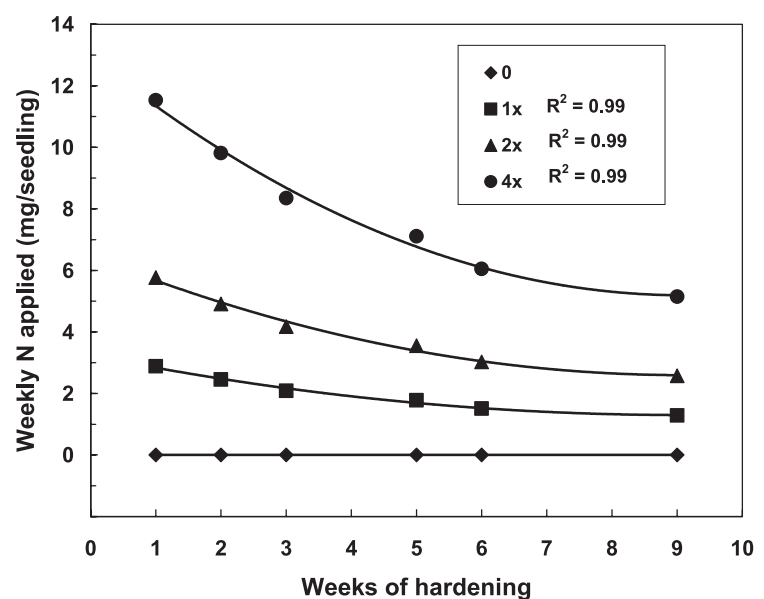

Figure 1. Late-season fertilization regimes: unfertilized (0), extended loading $(1 \times)$, intermediate super-loading $(2 \times)$, and high superloading (4x) treatments supplied cumulative totals of $0,12,24$ and $48 \mathrm{mg} \mathrm{N} \cdot$ seedling $^{-1}$, respectively, as a pre-mixed N, P, and $\mathrm{K}$ fertilizer solution. Delivery was scheduled for $6 \mathrm{wk}$, but was delayed for one and two weeks after wk 3 and 6, respectively, to allow adequate dry down and avoid leaching after fertilization.

treatments were expected to substantially build up nutrient reserves in seedlings during hardening (Fig. 1). All four treatments $(0,1 \times, 2 \times$ and $4 \times$ ) were arranged within each of the two pre-hardening (C or NL) regimes as a completely randomized design with three replications.

The fertilizer delivery schedules were based on a reverse exponential function that proportionately matched nutrient addition rate with exponentially declining growth and nutrient uptake rates [18] during hardening off $[1,5,11,47]$. In theory, the delivery schedule would avoid toxic accumulation of nutrients in the growing medium since nutrient addition rate is synchronized with plant growth and nutrient uptake rates $[5,18]$. Calculation of the nutrient addition rate $(r)$ was based on the function:

$$
N_{T}=\sum_{i=1}^{t} N_{f} e^{-r t}
$$

where $N_{T}$ is the total amount of nutrients applied for $t$ applications during hardening. The starting dose $\left(N_{f}\right)$ is equal to the final dose applied before hardening to avert potential nutrient stress during blackout [5]. Knowing $r$, the amount of fertilizer supplied for a specific application $\left(N_{t}\right)$ was computed as:

$$
N_{t}=N_{f} e^{-r t} .
$$

The same commercial fertilizer mix (enriched with extra $\mathrm{K}$ as $\mathrm{KCl}$ ) used before hardening was applied during hardening. Six $(t=6)$ weekly applications were scheduled, although the penultimate and final applications were delayed by one and two weeks, respectively, to allow adequate crop dry-down (Fig. 1). The required fertilizer amount (adjusted for over spray) was added to a watering can and sprayed on individual trays. Subsequently, trays were brought up to container capacity [50] with water only. At the end of the hardening period (week 36) seedlings were cold stored prior to outplanting.

\subsection{Bioassay outplanting trial}

The outplanting trial was comprised of 8 treatments: four within each of the conventional (C) and nutrient-loaded (NL) groups as unfertilized ( 0 ), extended loading $(1 \times)$, intermediate super-loading $(2 x)$ and high super-loading $(4 x)$. The test seedlings were planted on blocks of intact soil substrates retrieved from a mature black spruce stand (FEC site type 4; see [27]) near Cochrane, Ontario ( $49^{\circ} 04^{\prime} \mathrm{N}, 81^{\circ} 01^{\prime} \mathrm{W}$ ). The soil was a moderately drained, coarse sandy Orthic Humo-Ferric Podzol topped by a shallow organic layer. The ground cover was dominated by Pleurozium mosses. Thirty-two rectangular blocks of substrate $(36 \times 30 \mathrm{~cm})$ were cut to a depth of $15 \mathrm{~cm}$ without disturbing surface vegetation and placed into plastic containers with pre-drilled drainage holes to allow free drainage and aeration. The containers were transported to the University of Toronto and placed on elevated benches in heated and ventilated greenhouse. Growth conditions were: temperature $18-25^{\circ} \mathrm{C}$, humidity $65-85 \%$, and an extended 18 -h photoperiod supplemented with sodium vapor lamps at a light intensity of $250 \mu \mathrm{mol} \cdot \mathrm{s}^{-1} \mathrm{~m}^{-2}$ at crop level. Seedlings were presorted to similar size at planting to minimize confounding effects due to initial differences in pre-plant size. Each bioassay pot was a replicate of one treatment. The pot was planted with nine seedlings at about $10 \times 10 \mathrm{~cm}$ spacing. The pots were then arranged as a completely randomized design with four blocks as replicates. The pots were irrigated weekly to container capacity [50], and randomly re-arranged on the bench to reduce placement effects. 
Table II. Effects of nutrient loading on seedling dry mass, shoot:root ratio, and N, P and K concentration (\% dw) before hardening. The prehardening regimes: conventional and nutrient loaded treatments supplied cumulative totals of 19 and $74 \mathrm{mg} \mathrm{N} \cdot$ seedling $^{-1}$.

\begin{tabular}{lccccc}
\hline $\begin{array}{l}\text { Pre-hardening } \\
\text { fertilization regimes }\end{array}$ & $\begin{array}{c}\text { Plant dry mass } \\
(\mathrm{mg})\end{array}$ & $\begin{array}{c}\text { Shoot/root } \\
\text { ratio }\end{array}$ & & \multicolumn{2}{c}{ Nutrient concentration $(\% \mathrm{dw})$} \\
\cline { 4 - 6 } & & & $\mathrm{N}$ & $\mathrm{P}$ & $\mathrm{K}$ \\
\hline Conventional (C) & $560(33)$ & $2.73(0.14)$ & $1.33(0.02)$ & $0.26(0.01)$ & $0.67(0.01)$ \\
Nutrient loaded (NL) & $550(18)$ & $4.33(0.21)$ & $2.90(0.07)$ & $0.37(0.01)$ & $0.81(0.03)$ \\
\hline
\end{tabular}

$\dagger$ Means (and standard error in parentheses) were estimated from random samples of 3 groups of 5 seedlings per tray within each of the C or NL regime treatments at the end of pre-hardening phase.

\subsection{Sampling and statistical analyses}

Seedlings were sampled before (week 18) and after (week 36) the hardening phase, and before and after transplanting for 13 weeks in the bioassay pots (Tab. I). After harvest, growing media was rinsed from roots and shoot lengths were recorded. Thereafter, seedlings were separated into roots and shoots, oven dried at $70{ }^{\circ} \mathrm{C}$ for $48 \mathrm{~h}$, weighed, milled and composited by replicate or subsample for nutritional analysis according to Timmer and Armstrong [45]. Prehardening growth and nutrient responses were assessed on three subsamples of five trees each drawn from randomly selected trays reared under the conventional $(\mathrm{C})$ or nutrient loaded $(\mathrm{NL})$ regimes. Each regime was imposed in a separate part of the greenhouse without replication; hence results were presented as means and standard errors. Late-season fertilization responses were evaluated on a sample of five random seedlings per tray (replication) using a one-way ANOVA testing four treatments within each prehardening regime replicated three times. A similar one-way ANOVA was conducted on results from the outplanting trial based on the destructive sample of five trees per bioassay before and after transplanting. In this case there were eight treatments within the conventional (C) and nutrient loading (NL) regimes replicated three times. Significant treatment means were ranked according to Tukey's HSD test at $p<0.05$ [38].

\section{RESULTS AND DISCUSSION}

\subsection{Pre-hardening growth and nutrition}

Before late-season fertilization, pre-hardening nutrient loading increased seedling $\mathrm{N}, \mathrm{P}$ and $\mathrm{K}$ concentration without changing total dry mass (Tab. II), reflecting typical luxury uptake from extra fertilization since nutrient uptake was enhanced without biomass increase $[5,7,36]$. This finding concurs with results of Salifu and Timmer [37] where induced luxury consumption was associated with increased $\mathrm{N}$ content (150\%) in black spruce seedlings when compared to conventionally cultured plants. Pre-hardening $\mathrm{N}$ content for respective $\mathrm{C}$ and NL seedlings were 7.50 and $16.00 \mathrm{mg} \mathrm{N} \cdot$ plant $^{-1}$. Thus, nutrient loading raised $\mathrm{N}$ content by $113 \%$, and concentration level as high as $2.9 \% \mathrm{dw}$, which is close to the target considered optimum for nutrient loaded black spruce crops at the hardening stage [5, 37]. Shoot:root biomass ratio was also increased by nutrient loading (2.7-4.3) indicating proportionally more carbon partitioning to shoots rather than roots presumably because of greater nutrient availability in the growing medium [37]. Similarly, high soil N availability lowered root:shoot biomass ratios in longleaf pine (Pinus palustris Mill.) seedlings grown under water stress [21].

\subsection{Growth allocation and nutrient uptake during hardening}

After hardening off (week 36), late-season fertilization increased biomass production by $40-59 \%(p<0.3513$, Tab. III) in conventional $(\mathrm{C})$ and $47-70 \%(p<0.1611)$ in nutrient loaded (NL) seedlings demonstrating that considerable growth occurred during this period [5,32], although differences were not significant. As expected, most growth occurred in roots $(104 \%)$ as compared with shoots $(42 \%)$, lowering shoot:root ratios from 4.3 to 2.5 within the nutrient loaded regime $(p<$ $0.0838)$ and from 2.7 to 1.9 within the conventional regime $(p<$ 0.4954) (Tab. III and Fig. 2). This plastic response was presumably triggered by short-day treatments that induced bud-set and shifted carbon allocation to roots rather than shoots [5, 29]. Increased proliferation and development of the root systems is considered beneficial for newly planted seedlings. The carbon shift promotes nutrient and moisture acquisition in comparatively less fertile field soils, especially soon after planting when root extension is slow $[6,8]$.

Although total dry matter production was unaffected by lateseason fertilizer additions (Tab. III), $\mathrm{N}$ content was significantly increased by $44-167 \%(p<0.0001)$ in the NL-treated seedlings, and by $100-312 \%(p<0.0001)$ in the C-treated seedlings, demonstrating significant luxury uptake of $\mathrm{N}$ in both regimes (Fig. 3). The accumulation was stimulated by higher $\mathrm{N}$ rates illustrating the efficacy of supplemental fertilization at this stage in the greenhouse rotation. Plant $\mathrm{N}$ concentration ranged from $1.33-2.90 \% \mathrm{dw}$ before hardening and $0.93-4.36 \%$ $\mathrm{dw}$ after hardening (Tabs. II and III). Evidently, growth dilution (reduced $\mathrm{N}$ concentration) occurred in unfertilized (0) seedlings and $\mathrm{N}$ built up in fertilized $(1 \times, 2 \times, 4 \times)$ seedlings in both $\mathrm{C}$ and $\mathrm{NL}$ regimes. For instance, late-season fertilization raised $\mathrm{N}$ concentration by $265 \%(p<0.0001)$ and $61 \%(p<$ 0.0001 ) within $\mathrm{C}$ and NL regimes, respectively, when compared to controls (Tab. III). Overall concentrations were higher than those reported (maximum $2.88 \% \mathrm{dw}$ ) in our previous study [5], apparently because of longer (6 vs. 9 wks) and (or) higher (12 vs. $48 \mathrm{mg} \mathrm{N}$-seedling ${ }^{-1}$ ) rates of late-season fertilization. These trends although high, are in general agreement with results of other studies $[19,39]$ where fall $\mathrm{N}$ fertilization benefited seedling nutrition by increasing $\mathrm{N}$ concentration and contents in plant tissues that subsequently stimulated growth during outplanting.

Phosphorus uptake was also improved by $12-20 \%(p<$ 0.0235) within NL-regime seedlings during hardening (Fig. 3), but not as markedly as with $\mathrm{N}$. The difference probably reflects that $\mathrm{N}$ is more readily incorporated into organic molecules than $\mathrm{P}$, 


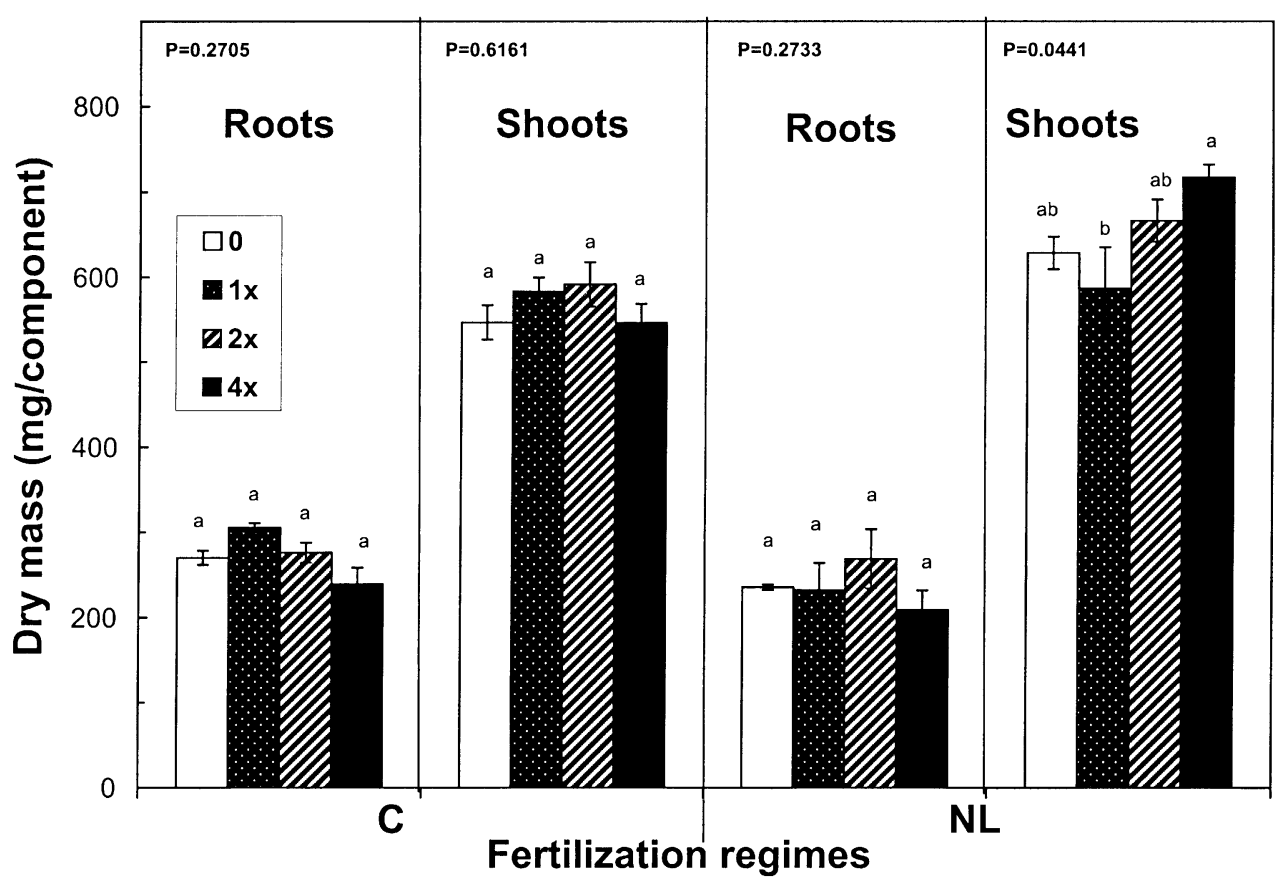

Figure 2. Root and shoot dry mass after late-season fertilization. Treatments as indicated in Figure 1. Bars represent one standard error of the mean. For each plant component, bars sharing the same letter within regime are not statistically different according to Tukey's HSD test $(\alpha=0.05)$.

Table III. Effects of late-season fertilization on seedling dry mass, shoot:root ratio, and N, P and K concentration (\% dw) and associated ANOVA. The two pre-hardening regimes: conventional (C) and nutrient loaded (NL) supplied cumulative totals of 19 and 74 mg N·seedling ${ }^{-1}$. The four late-season fertilization treatments conducted within each regime were: control (0), extended loading (1×), intermediate super loading (2x) and high super loading (4x) supplying cumulative totals of 012,24 and $48 \mathrm{mg} \mathrm{N} \cdot$ seedling $^{-1}$.

\begin{tabular}{|c|c|c|c|c|c|c|}
\hline \multirow{2}{*}{$\begin{array}{l}\text { Prehardening } \\
\text { fertilization }\end{array}$} & \multirow{2}{*}{$\begin{array}{l}\text { Late-season } \\
\text { fertilization }{ }^{\dagger}\end{array}$} & \multirow{2}{*}{$\begin{array}{l}\text { Plant dry mass } \\
\qquad(\mathrm{mg})\end{array}$} & \multirow{2}{*}{$\begin{array}{l}\text { Shoot/root } \\
\text { ratio }\end{array}$} & \multicolumn{3}{|c|}{ Nutrient concentration (\% dw) } \\
\hline & & & & $\mathrm{N}$ & $P$ & K \\
\hline \multicolumn{7}{|l|}{ C-regime } \\
\hline & 0 & $817 \mathrm{a}$ & $2.06 \mathrm{a}$ & $0.93 \mathrm{~d}$ & $0.21 b$ & $0.61 \mathrm{a}$ \\
\hline & $1 \times$ & $888 \mathrm{a}$ & $1.90 \mathrm{a}$ & $1.78 \mathrm{c}$ & $0.31 \mathrm{a}$ & $0.77 \mathrm{a}$ \\
\hline & $2 \times$ & $867 \mathrm{a}$ & $2.17 \mathrm{a}$ & $2.79 \mathrm{~b}$ & $0.32 \mathrm{a}$ & $0.69 \mathrm{a}$ \\
\hline & $4 \times$ & $785 \mathrm{a}$ & $2.32 \mathrm{a}$ & $3.39 \mathrm{a}$ & $0.28 \mathrm{a}$ & $0.68 \mathrm{a}$ \\
\hline \multicolumn{7}{|l|}{ NL-regime } \\
\hline & 0 & $863 \mathrm{a}$ & $2.75 \mathrm{a}$ & $2.71 \mathrm{c}$ & $0.33 \mathrm{a}$ & $0.68 \mathrm{~b}$ \\
\hline & $1 \times$ & $818 \mathrm{a}$ & $2.54 \mathrm{a}$ & $3.52 b$ & $0.33 \mathrm{a}$ & $0.69 b$ \\
\hline & $2 \times$ & $935 \mathrm{a}$ & $2.50 \mathrm{a}$ & $3.86 \mathrm{~b}$ & $0.34 \mathrm{a}$ & $0.80 \mathrm{~b}$ \\
\hline & $4 \times$ & $926 \mathrm{a}$ & $3.43 \mathrm{a}$ & $4.36 \mathrm{a}$ & $0.36 \mathrm{a}$ & $1.40 \mathrm{a}$ \\
\hline \multicolumn{7}{|l|}{ ANOVA $p>$ F } \\
\hline C-regime & & 0.3513 & 0.4954 & 0.0001 & 0.0001 & 0.1639 \\
\hline NL-regime & & 0.1611 & 0.0838 & 0.0001 & 0.1757 & 0.0001 \\
\hline
\end{tabular}

$\lceil$ Late-season fertilization means $(0,1 \times, 2 \times$ and $4 \times)$ sharing similar letters within each regime $(\mathrm{C}$ or NL) are not significantly different according to Tukey's HSD test, $p<0.05$.

and (or) that more $\mathrm{N}(20 \%)$ than $\mathrm{P}(9 \%)$ was supplied in the fertilizer formulation [29]. Super-loading $(2 \times, 4 \times$ rates) raised $\mathrm{P}$ concentrations of conventional $(\mathrm{C})$ seedlings (range 0.26
$0.32 \% \mathrm{dw}$ ) but lowered (range $0.37-0.33 \% \mathrm{dw}$ ) levels of the nutrient loaded (NL) seedlings that were initially high (Tab. III). The relatively low (12-20\%) boost in P uptake suggests that 


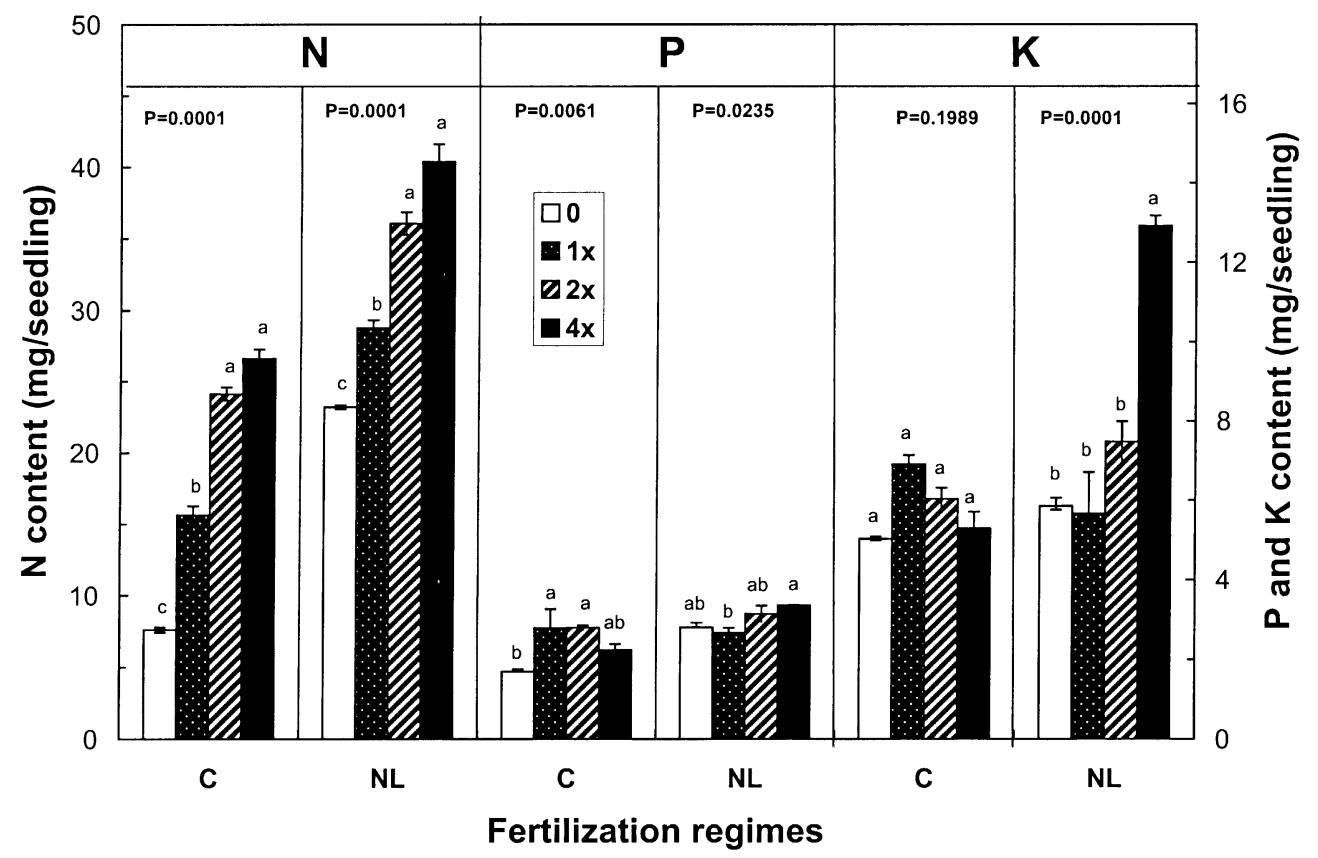

Figure 3. Seedling N, P, and K content after late-season fertilization. Treatments as indicated in Figure 1. Bars represent one standard error of the mean. For each nutrient, bars sharing similar letters within regime are not statistically different according to Tukey's HSD test $(\alpha=0.05)$.

higher $\mathrm{P}$ additions may be necessary for late-season fertilization to maintain steady-state levels.

Ammonium $\left(\mathrm{NH}_{4}^{+}\right)$and potassium $\left(\mathrm{K}^{+}\right)$ion uptake appear to be similar and competitive [14]. Consequently, $\mathrm{K}$ uptake may decline with high $\mathrm{N}$ supply $[16,51]$ because $\mathrm{NH}_{4}{ }^{+}$acts as an uptake antagonist to $\mathrm{K}$ [15]. Increased $\mathrm{K}$ addition may counter this effect for conifer nursery stock [49]. This inhibitory effect was noted in our previous study with late-season fertilized black spruce [5], but was not evident here presumably because of the higher K (30\%) supplied (Fig. 3). Seedling K uptake was unchanged by late-season fertilization in the Cregime $(p<0.1989)$, but was increased $(p<0.0001)$ by $28 \%$ and $121 \%$ in the $2 \times$ - and $4 \times$-treated seedlings, respectively, of the NL-regime (Fig. 3). As expected, K concentration was reduced (diluted) in unfertilized (0) seedlings, but levels remained at steady-state (undiluted) after super-loading signifying that the extra high $\mathrm{K}$ application was adequate for late season applications (Tabs. II and III). The exception was elevated $\mathrm{K}(1.40 \% \mathrm{dw})$ in the high super-loaded $(4 \times)$ seedlings of the nutrient loaded (NL) regime, which may reflect excess accumulation (Tab. III).

\subsection{Outplanting response}

When outplanted on bioassays for a 13-week growing period, late-season fertilization $(1 \times, 2 \times$, and $4 \times$ rates $)$ increased biomass production as much as $78 \%$ for conventional (C) and $115 \%$ for nutrient loaded (NL) $(p<0.0001)$ seedlings when compared to the C-regime controls (Fig. 4a). There was no mortality, except for some $(30 \%)$ of the nutrient loaded $4 \times$ treated trees that were associated with the highest shoot/root ratio (4.33) and highest $\mathrm{N}$ and $\mathrm{K}$ concentration (4.36 and 1.40\% $\mathrm{dw}$ ) before transplanting (Tab. III). Growth response was also sub-maximum for the surviving trees (Fig. 4a), suggesting possible moisture stress and (or) excessive nutrient accumulation. Although pre-plant biomass of all treatments was similar $(p<$ 0.1163 ) (Fig. 4a), N content differed $(p<0.0001)$ widely, depending on loading intensity (Fig. 4b). Presumably the higher reserves functioned as a crucial $\mathrm{N}$ source that was rapidly remobilized for sinks of new growth when outplanted [33, $34,36]$.

Growth increases in new shoots were closely associated with amounts of $\mathrm{N}$ accumulated in these shoots (Fig. 4). In contrast, $\mathrm{N}$ content in old shoots declined to a common threshold range (8-10 mg N) presumably reflecting mostly structurally bound $\mathrm{N}$ [7]. The decline signified substantial $\mathrm{N}$ depletion, particularly for loaded seedlings. Most $\mathrm{N}$ in new growth originates from two main sources: internally from plant tissues and externally from the soil $[33,36]$. Assuming that the old and new shoots act as respective major source and sink for nutrients [23, 36 ], $\mathrm{N}$ content differences in old shoots before and after planting provide estimates of net $\mathrm{N}$ retranslocated to new growth. The remaining $\mathrm{N}$ in new shoots then represent estimates of soil derived $\mathrm{N}$ [24, 26, 32]. Nitrogen distribution among seedling components in Figure $4 \mathrm{~b}$ shows that net $\mathrm{N}$ retranslocation (or net $\mathrm{N}$ depletion from old shoots to new growth) was associated with higher pre-plant $\mathrm{N}$ reserves built up by pre-hardening nutrient loading and late-season fertilization [25, 28, 43, 49, 51]. The depletion was most severe for nutrient loaded (NL) rather than conventional $(\mathrm{C})$ regime seedlings (max. 10 vs. $18 \mathrm{mg} \mathrm{N}$, see Fig. 4b), exemplifying typical "opportunistic" 
(a)

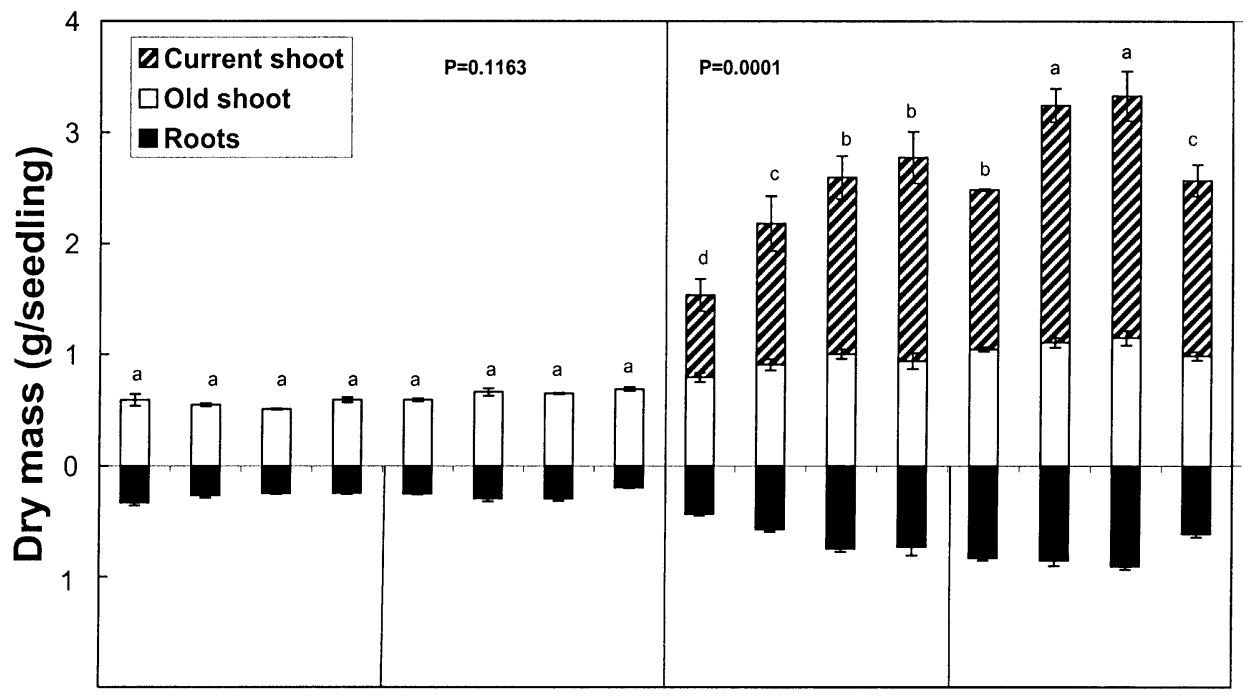

(b)

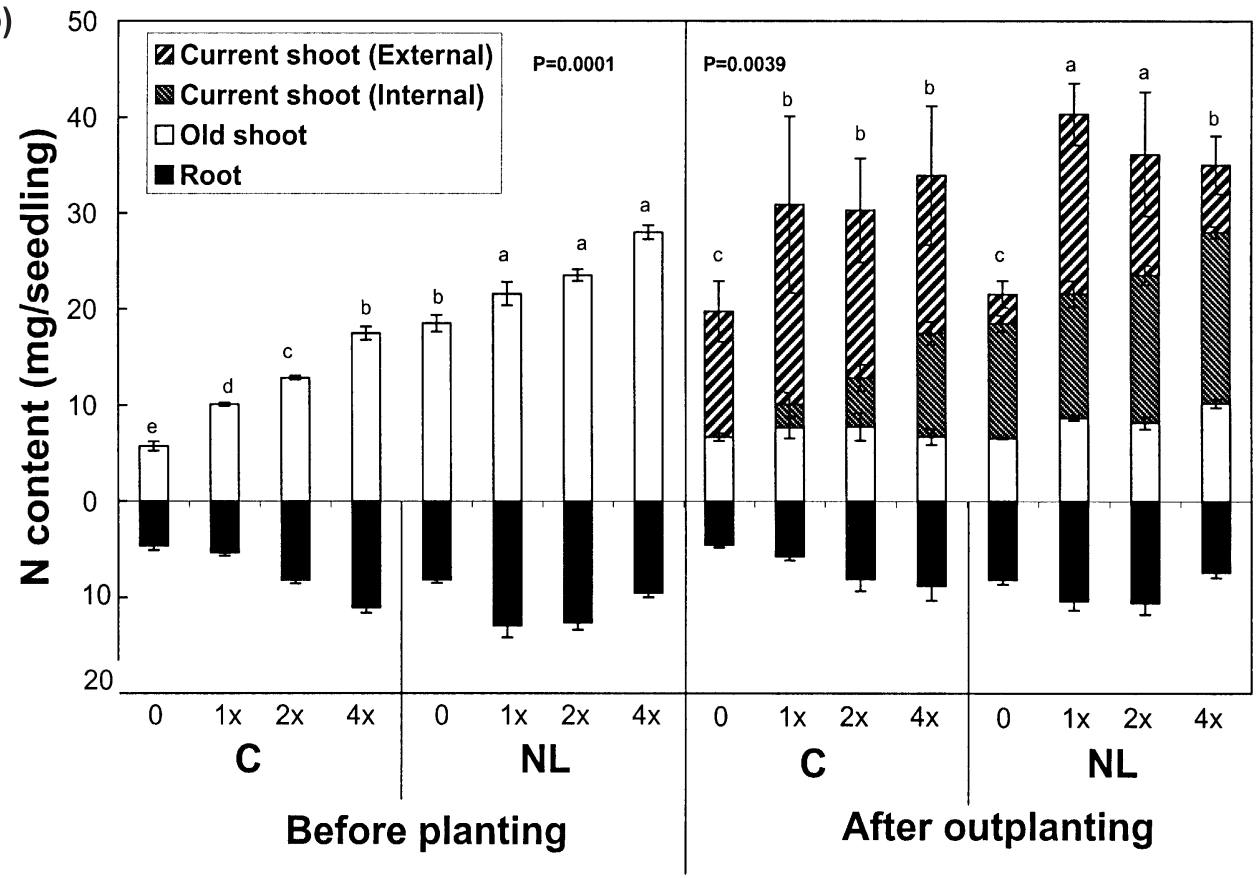

Figure 4. Component dry mass (a) and $\mathrm{N}$ content (b) of conventional (C) and nutrient loaded (NL) seedlings before and after transplanting on intact bioassays of soil substrates retrieved from a Boreal forest site. Vertical error bars are standard errors of the mean. Late-season fertilization means $(0,1 \times, 2 \times$ and $4 \times$ as in Fig. 1$)$ sharing the same letter before or after outplanting are not statistically different according to Tukey's HSD test $(\alpha=0.05)$.

and "conservative" nutrient use strategies for respective loaded and non-loaded seedlings [24]. Thus, retranslocation met about $11-40 \%$ of the $\mathrm{N}$ required for new growth in C-regime seedlings and up to $72-80 \%$ in NL-regime plants, demonstrating the efficacy of loading to meeting sink demand for $\mathrm{N}$ through internal cycling $[24,36]$. Isotope studies have shown black spruce seedlings can rely entirely on $\mathrm{N}$ retranslocation (100\%) to meet early growth demands in [36], a capacity enhanced by nutrient loading. Conventionally reared seedlings were more dependent on soil derived $\mathrm{N}$ (as high as 77\%), suggesting these plants may be more prone to nutrient stress when planted on competitive or poor fertility sites [24].

Although root biomass increased substantially after planting (31-231\%), N uptake (content) in roots changed relatively little (1-28\%) (Fig. 4). These responses contrast with higher $\mathrm{N}$ accumulations in shoots, which seems to support the contention that the expanding shoot system is the primary sink for retranslocated nutrients in newly planted seedlings [7]. This allocation pattern promotes light capture and photosynthesis $(6,13,24,26)$. It must be kept in mind, however, that the 13 -week outplanting 
period represented the summer growing season only, hence root system $\mathrm{N}$ reserves may build up later in the autumn as found by others $[3,25,28]$.

\subsection{Implications}

The improved growth and nutritional status of the intensively fertilized seedlings after planting demonstrate the potential benefit of nutrient loading and late-season fertilization practices on early plantation performance. Accelerated outplant growth and enhanced nutrition is consistent with our hypothesis and concurs with results of other studies [19, 28, 39, 40]. The increased biomass of seedlings may be partly attributed to higher photosynthetic rates associated with increased $\mathrm{N}$ status $[13,41]$ that promote soluble protein accumulation for carboxylation during photosynthesis. There is of course a limit to the intensity of nutrient loading of seedlings. Our results show that the high super-loading rate $\left(48 \mathrm{mg} \mathrm{N}\right.$-seedling $\left.{ }^{-1}\right)$ is toxic for black spruce culture, particularly when raised in relatively small volume containers. Based on short term responses so far, intermediate super-loading ( $24 \mathrm{mg} \mathrm{N}$-seedling $^{-1}$ ) was most effective in stimulating nutrient accumulation in the nursery and promoting outplanting response with both conventional and nutrient loaded seedlings.

The bioassay approach adopted in this study is considered an effective tool for evaluating initial outplanting response of seedlings. Other studies have noted close correspondence between first year growth responses of nutrient loaded black spruce seedlings under field conditions with growth on intact soil bioassays [23, 31]. Consequently, our results may have relevance to expected stock performance at plantation establishment. A field trial in northern Ontario has shown that prehardening nutrient loading increased tree biomass by $39 \%$ when compared with non-loaded plants after two growing seasons [23]. A similar trial noted $49 \%$ more biomass after 6 years [42]; indicating some persistence in the loading response probably because of initial growth and nutritional advantages at plantation establishment. These findings suggest that nutrient loading at both the pre-hardening and hardening stage in the nursery may contribute to shortening the time required to attain crown closure, thus reducing competition with neighboring vegetation [19].

\section{CONCLUSIONS}

Super-loading regimes significantly increased $\mathrm{N}$ uptake, which prevented $\mathrm{N}$ dilution, and consistently stimulated $\mathrm{N}$ accumulation in seedlings during hardening. These results suggest that nutrient loading practices can effectively be prolonged until the end of greenhouse culture to build up greater nutrient reserves for outplanting. The intermediate super loading $(2 \times)$ treatment was most effective in promoting nutrient storage in plants during hardening. This treatment was also associated with improved outplanting response and is recommended for late-season nutrient loading of black spruce seedlings. Potassium dilution was averted with high $\mathrm{K}$ enrichment of the fertilizer mix, but extra P may be needed to maintain steady-state uptake and avoid $\mathrm{P}$ imbalance under intensive super-loading. When outplanted for a 13 -week period, biomass production increased by $115 \%$ in intermediate super loaded compared with conventionally reared seedlings. However, higher loading intensities may induce mortality. The improved growth response was associated with increased retranslocation (72$80 \%$ ) of built-up nutrient reserves to sites of new growth. Higher tissue nutrient concentration and uptake rates by loaded seedlings may have promoted photosynthesis that improved growth in these plants. Results show that nutrient loading during the entire greenhouse rotation enhanced outplanting performance on pot bioassays, and may contribute to the success of reforestation efforts in Ontario.

Acknowledgments: We are sincerely thankful to Abe Aidelbaum, Terry White, and the staff at North Gro Development Ltd. for dedicated assistance and support for this study. Financial support from the National Science and Engineering Research Council of Canada is greatly acknowledged. We are also grateful to the anonymous referees for constructive criticism of the manuscript.

\section{REFERENCES}

[1] Bigras F.J., D’Aoust A.L., Hardening and dehardening of shoots and roots of containerized black spruce and white spruce seedlings under short and long days, Can. J. For. Res. 22 (1992) 388-396.

[2] Bigras F.J., Gonzalez A., D’Aoust A.L., Herbet C., Frost hardiness, bud phenology and growth of containerized Picea mariana seedlings grown at three nitrogen levels and three temperature regimes, New For. 12 (1996) 243-259.

[3] Birchler T.M., Rose R., Haase D.L., Fall fertilization with N and K: Effects on Douglas-Fir seedling quality and performance, West. J. Applied For. 16 (2001) 71-79.

[4] Blake J., Zaerr J., Hee S., Controlled moisture stress to improve cold hardiness morphology of Douglas-fir seedlings, For. Sci. 25 (1979) 576-582.

[5] Boivin J.R., Miller B.D., Timmer V.R., Late-season fertilization of Picea mariana seedlings under greenhouse culture: biomass and nutrient dynamics, Ann. For. Sci. 59 (2002) 255-264.

[6] Burdett A.N., Physiological processes in plantation establishment and the development of specifications for forest planting stock, Can. J. For. Res. 20 (1990) 415-427.

[7] Chapin F.S.III., Adaptation and physiological response of wild plants to nutrient stress, in: Gabelman H.W., Loughman B.C. (Eds.), Genetic aspects of plant mineral nutrition, Kluwer Academic Publishers, The Netherlands, 1987, pp. 15-25.

[8] Chapin F.S.III., The ecology and economics of storage in plants, Ann. Rev. Ecol. Syst. 21 (1990) 423-447.

[9] Colombo S.J., Bud dormancy status, frost hardiness, shoot moisture content, and readiness of black spruce container seedlings for frozen storage, J. Am. Soc. Hort. Sci. 115 (1990) 302-307.

[10] Colombo S.J., Frost hardening spruce container stock for overwintering in Ontario, New For. 13 (1997) 449-467.

[11] Colombo S.J., Webb D.P., Glerum C., Frost hardiness testing: An operational manual for use with extended greenhouse culture, Ontario Ministry of Natural Resources, Forest Research Report No. 110, 1984.

[12] Colombo S.J., Zhao S., Blumwald E., Frost hardiness gradients in shoots and roots of Picea mariana seedlings, Scand. J. For. Res. 10 (1995) 32-36.

[13] Evans J.R., Photosynthesis and nitrogen relationships in leaves of $\mathrm{C}_{3}$ plants, Oecologia 78 (1989) 9-19.

[14] Flaig H., Mohr H., Assimilation of nitrate and ammonium by Scots pine (Pinus sylvestris) seedling under conditions of high nitrogen supply, Physiol. Plant. 84 (1992) 568-576.

[15] Hüttl R.F., Nutrient supply and fertilizer experiments in view of $\mathrm{N}$ saturation, Plant Soil 128 (1990) 45-58. 
[16] Imo M., Timmer V.R., Nitrogen uptake of mesquite seedlings at conventional and exponential fertilization schedules, Soil Sci. Soc. Am. J. 56 (1992) 927-934.

[17] Imo M., Timmer V.R., Vector diagnosis of nutrient dynamics in mesquite seedlings, For. Sci. 43 (1997) 268-273.

[18] Ingestad T., Lund A.B., Theory and technique for steady state mineral nutrition and growth of plants, Scand. J. For. Res. 1 (1986) 439-453.

[19] Irwin K.M., Duryea M.L., Stone E.L., Fall-applied nitrogen improves performance of 1-0 Slash pine nursery seedlings after outplanting, South J. Appl. For. 22 (1998) 111-116.

[20] Jobidon R., Charette L., Bernier P.Y., Initial size and competing vegetation effects on water stress and growth of Picea mariana (Mill.) BSP seedlings planted in three different environments, For. Ecol. Manage. 103 (1998) 293-305.

[21] Jose S., Merritt S., Ramsey C.L., Growth, nutrition, photosynthesis and transpiration responses of longleaf pine seedlings to light, water and nitrogen, For. Ecol. Manage. 180 (2003) 335-344.

[22] Landis T.D., Tinus R.W., McDonald S.E., Barnett J.P., Seedling nutrition and irrigation, Vol. 4, The Container Tree Nursery Manual, Agric. Handbk. 674, Washington DC, US Dept. Agric. For. Ser., 1989.

[23] Malik V., Timmer V.R., Growth, nutrient dynamics, and interspecific competition of nutrient-loaded black spruce seedlings on a boreal mixedwood site, Can. J. For. Res. 26 (1996) 1651-1659.

[24] Malik V., Timmer V.R., Biomass partitioning and nitrogen retranslocation in black spruce seedlings on competitive mixedwood sites: a bioassay study, Can. J. For. Res. 28 (1998) 206-215.

[25] Margolis A.H., Waring R.H., Carbon and nitrogen allocation patterns of Douglas-fir seedlings fertilized with nitrogen in autum. II Field performance, Can. J. For. Res. 16 (1986) 903-909.

[26] McAlister J.A., Timmer V.R., Nutrient enrichment of white spruce seedlings during nursery culture and initial plantation establishment, Tree Physiol. 18 (1998) 195-202.

[27] McCarthy T.G., Arnup R.W., Nieppola J., Merchant B.G., Taylor K.C., Parton W.J., Field guide to forest ecosystems of northeastern Ontario, Queen's Printer for Ontario, NEST field guide, 1994.

[28] Millard P., Proe M.F., Nitrogen uptake, partitioning and internal cycling in Picea sitchensis (Bong.) Carr. as influenced by nitrogen supply, New Phytol. 125 (1993) 113-119.

[29] Miller B.D., Timmer V.R., Nutrient dynamics and carbon partitioning in nutrient loaded Picea mariana [Mill.] B.S.P. seedlings during hardening, Scand. J. For. Res. 12 (1997) 122-129.

[30] Munson A.D., Bernier P.Y., Comparing natural and planted black spruce seedlings. II. Nutrient uptake and efficiency of use, Can. J. For. Res. 23 (1993) 2435-2442.

[31] Munson A.D., Timmer V.R., Site-specific growth and nutrition of planted Picea mariana in the Ontario Clay Belt. II. Effects of nitrogen fertilization, Can. J. For. Res. 19 (1989) 171-178.

[32] Nambiar E.K.S., Fife D.N., Growth and nutrient retranslocation in needles of radiata pine in relation to nitrogen supply, Ann. Bot. 60 (1987) 147-156.

[33] Nambiar E.K.S., Fife D.N., Nutrient retranslocation in temperate conifers, Tree Physiol. 9 (1991) 185-207.
[34] Proe M.F., Millard P., Relationships between nutrient supply, nitrogen partitioning and growth in young sitka spruce (Picea sitchensis), Tree Physiol. 14 (1994) 75-88.

[35] Rikala R., Repo T., The effect of late summer fertilization on the frost hardening of second-year Scots pine seedlings, New For. 14 (1997) 33-44.

[36] Salifu K.F., Timmer V.R., Nitrogen retranslocation response of young Picea mariana to nitrogen-15 supply, Soil Sci. Soc. Am. J. 67 (2003) 309-317.

[37] Salifu K.F., Timmer V.R., Optimizing nitrogen loading in Picea mariana seedlings during nursery culture, Can. J. For. Res. 33 (2003) 1287-1294.

[38] SAS Institute Inc., SAS/START user's guide, Cary, N.Y., Vol. 8, Version 6, 1989.

[39] South D.B., Donald D.G.M., Effect of nursery conditioning treatments and fall fertilization on survival and early growth of Pinus taeda seedlings in Alabama, USA, Can. J. For. Res. 32 (2002) $1171-1179$.

[40] Sung S.S., Black C.C., Kormanik T.L., Zarnoch S.J., Kormanik P.P., Counce P.A., Fall nitrogen fertilization and the biology of Pinus taeda seedling development, Can. J. For. Res. 27 (1997) $1406-1412$.

[41] Tan W., Hogan G.D., Limitations to net photosynthesis as affected by nitrogen status in jack pine (Pinus banksiana Lamb.) seedlings, J. Exp. Bot. 46 (1995) 407-413.

[42] Timmer V.R., Exponential fertilization and nutrient loading of planting stock for vegetation control, in: Proc. 20th Annual Forest Vegetation Management Conference, 19-21 Jan., Redding, CA, 1999 , pp. 77-81.

[43] Timmer V.R., Interpretation of seedling analysis and visual symptoms, in: van den Driessche R. (Ed.), Mineral nutrition of conifer seedlings, CRC Press Boca Raton, FL, USA, 1991, pp. 113-114.

[44] Timmer V.R., Aidelbaum A., Manual for exponential nutrient loading of seedlings to improve outplanting performance on competitive forest sites, Nat. Res. Canada. Can. For. Ser., Sault Ste Marie, On. NODA/NFP Tech. Rep. TR25, 1996.

[45] Timmer V.R., Armstrong G., Growth and nutrition of containerized Pinus resinosa at exponentially increasing nutrient additions, Can. J. For. Res. 17 (1987) 644-647.

[46] Timmer V.R., Armstrong G., Growth and nutrition of containerized Pinus resinosa seedlings at varying moisture regimes, New For. 3 (1989) 171-180.

[47] Timmer V.R., Armstrong G., Miller B.D., Steady-state nutrient preconditioning and early outplanting performance of containerized black spruce seedlings, Can. J. For. Res. 21 (1991) 585-594.

[48] Van den Dreissche R., Late-season fertilization, mineral nutrien reserves, and retranslocation in planted Douglas-fir (Pseudotsuga menziesii (Mirb.) Franco) seedlings, For. Sci. 31 (1985) 485-496.

[49] Van den Dreissche R., Ponsford D., Nitrogen induced potassium deficiency in white spruce (Picea glauca) and Engleman spruce (Picea engelmannii) seedlings, Can. J. For. Res. 25 (1995) 1445 1454.

[50] White J.W., Mastalerz J.W., Soil moisture as related to container capacity, Am. Soc. Hortic. Sci. 89 (1966) 758-765.

[51] Xu X., Timmer V.R., Biomass and nutrient dynamics of Chinese fir seedlings under conventional and exponential fertilization regimes, Plant Soil 203 (1998) 313-322. 